\title{
Changes in the menu of manipulation: Electoral fraud, ballot stuffing, and voter pressure in the 2011 Russian election
}

\author{
Cole J. Harvey \\ University of North Carolina, Chapel Hill, 361 Hamilton Hall CB\#3265, UNC-CH, Chapel Hill, NC 27599-3265, United States
}

\section{A R T I C L E I N F O}

\section{Article history:}

Received 16 July 2014

Received in revised form

6 July 2015

Accepted 17 November 2015

Available online 19 November 2015

\section{Keywords:}

Vote-buying

Electoral manipulation

Hybrid regime

Electoral authoritarianism

Patronage

Russia

\begin{abstract}
A B S T R A C T
Vote-buying and voter intimidation are costly, complicated, and risky ways to manage elections. Why, then, do hybrid regimes utilize such tactics rather than ballot stuffing or election falsification? Such methods to mobilize voters require the construction of patronage networks that can be used to mobilize or demobilize clients beyond the election, and to display the incumbent's organizational strength. These networks are most valuable in places where opposition groups are active; consequently direct voter pressure should be more common in competitive areas. This paper uses data from Russia's 83 regions during the 2011 election to compare patterns of extra-legal mobilization with patterns of ballot stuffing and falsification. I conclude that local political competitiveness structures the mix of electoral manipulation tactics employed.
\end{abstract}

(C) 2015 Elsevier Ltd. All rights reserved.

\section{Introduction: extra-legal mobilization and hybrid regimes}

Why do hybrid regimes engage in vote-buying and other methods of directly pressuring voters, when they have a number of other tools with which to manipulate elections? Such extra-legal mobilization efforts require the development of networks that link patrons, brokers, and voters; brokers and voters must be monitored to ensure they do not defect. As a result of the size of these networks and the principal-agent problems inherent in them, extra-legal mobilization efforts are costly, complicated, inefficient, and risky. Why is it that governments in hybrid regimes do not forego extra-legal mobilization, and devote those resources to more efficient forms of social control? I argue that this puzzle, which has not been fully addressed in the literature on authoritarian elections or election manipulation, can be resolved by understanding that the costs and benefits of electoral manipulation vary by the tactic used. Incumbents take advantage of these costs and benefits by adjusting the mix of tactics they employ in response to local political conditions. Like other forms of manipulation, extra-legal mobilization helps improve the incumbent's vote-share in the election. However, it also has additional benefits that are most valuable in competitive conditions.

E-mail address: harveyc@live.unc.edu.
Extra-legal mobilization requires a network of patronage that can be used to mobilize or demobilize clients. Deploying these networks to influence voters sends a signal of the incumbent's organizational strength and resources to other political actors. Due to these two indirect benefits, extra-legal mobilization is most valuable to incumbents where the risk of opposition mobilization is highest, since these networks and signals can be used to counteract opposition activity. It is difficult to test this theory directly using measures of opposition activity, since the theory predicts that extra-legal mobilization is both a response to, and deterrent of, opposition action. Instead, I test the theory by 1 ) adapting existing methods of election forensics to estimate three types of electoral manipulation: falsification of results, ballot stuffing, and extra-legal mobilization, and 2) demonstrating that use of these tactics varies in response to indicators of political competitiveness. I apply these methods to electoral results from Russia's 83 regions during the 2011 parliamentary election. I find that local political competitiveness structures the mix of tactics used to manipulate the election: falsification occurs primarily in the least competitive regions, ballot stuffing is equally common at middle and high levels of competitiveness, and extra-legal mobilization becomes increasingly common as competitiveness increases.

This paper contributes to a growing literature on the politics of electoral authoritarian (or hybrid) regimes. Research in this tradition has made great progress in demonstrating the functions that 
ostensibly democratic institutions like elections and legislatures can play in sustaining authoritarian governments. Multi-party elections allow authoritarian rulers to co-opt the opposition (Gandhi and Przeworski, 2007; Gandhi, 2008), to channel their demands into the structured setting of the legislature (Gandhi and Przeworski, 2006), to gather information (Boix and Svolik, 2013), or to deter elite defections (Magaloni, 2006). Elections and ruling parties can be a means of binding together elites and managing elite disagreements (Brownlee, 2007; Blaydes, 2011). In short, electoral competition serves as a mechanism whereby authoritarian rulers distribute patronage resources and policy influence to those lower-level politicians who demonstrate loyalty and effectiveness at managing elections (Lust-Okar, 2006; Malesky and Schuler, 2010; Reuter and Robertson, 2012).

Elections have been shown to be stabilizing for authoritarian regimes in most cases, but they still pose risks. They provide an opportunity for opposition groups-both domestic and international-to organize and mobilize against the regime (Bunce and Wolchik, 2010; Donno, 2013; Lindberg, 2009), and can also trigger mass protest, as the so-called color revolutions demonstrate (Tucker, 2007). Compared to the literature on hybrid institutions, we know less about the means by which governments in hybrid regimes manage elections in order to avoid these undesirable outcomes. This article contributes to our understanding by demonstrating that proregime actors in a hybrid regime vary the tactics they use to manipulate elections across the territory of the regime, in response to the capacity of the opposition to mobilize its own supporters.

\section{Theory: extra-legal mobilization and (de)mobilizing patronage networks}

Authoritarian leaders have a variety of tools at their disposal with which to manage elections. These can range from pre-election limitations on the opposition to post-election nullification of the results (Schedler, 2002). One option authoritarian governments have on election day is extra-legal mobilization, which I define as an attempt to pressure actual voters to support a party or candidate through benefits (such as a cash payment) or sanctions (such as the threat of job loss). This project seeks to understand the conditions under which governments engage in extra-legal mobilization rather than rely on other tools like falsification of the vote count or ballot stuffing. In particular, it addresses a puzzle that has gone thus far gone unanswered in the literature on election fraud in authoritarian countries. Extra-legal mobilization efforts are costly, as they require a network of brokers to identify potential opponents and supporters, disburse payments, and monitor compliance. Authoritarian election managers have been shown to change manipulation strategies with relative ease, manipulating the vote count when methods like ballot-stuffing are too easily observed (Sjoberg, 2013). Why then do authoritarian governments engage in costly, inefficient efforts to mobilize voters through intimidation and votebuying when they have the capacity to manipulate election results more directly?

In the following paragraphs I will show that extra-legal mobilization is costly and suffers from drawbacks that falsification and ballot stuffing do not. As a result, I argue that extra-legal mobilization should be employed where its indirect, non-electoral benefits are most valuable. Extra-legal mobilization requires the construction and display of patronage networks that could be used to mobilize or demobilize clients when necessary, such as in the event of opposition protest. Extra-legal mobilization can also send signals to other political actors about the incumbent regime's resources, helping induce cooperation. I hypothesize that these two benefits increase in value as the ability of opposition groups to organize increases, and as a result extra-legal mobilization efforts should be more common and intensive in competitive regions. ${ }^{1}$

\subsection{Cost of extra-legal mobilization vs. election fraud and ballot stuffing}

Extra-legal mobilization can encompass a variety of different means of influencing voters. ${ }^{2}$ Political machines can make direct payments to voters (Stokes, 2005; Nichter, 2008), pressure employers to ensure their employees vote for the ruling party (Frye et al., 2014), and more. In any case, voters must be rewarded for voting correctly. Consequently, extra-legal mobilization of any kind requires the development of networks that allow patrons to monitor clients, and to transfer rewards and punishments. These networks are usually mediated by one or more levels of brokers, with actors at each level responsible for overseeing a larger number of actors at the next level down (Knoke, 1990; Lazar, 2007; Auyero, 2007; Holzner, 2007). These pyramidal networks are inherently vulnerable to principal-agent problems (Kitschelt and Wilkinson, 2007).

The resulting networks are complex, costly and inefficient. At every level of the pyramidal network linking patrons and clients, brokers must be deterred from diverting resources for their own private gain and clients must be monitored (Kitschelt and Wilkinson, 2007). One study of vote-buying in a district election in Taiwan found that at least $45 \%$ of voters who had received a payment from the Kuomintang voted for a different candidate, despite the efforts of an organized and well-funded vote-buying machine. Motivating large numbers of voters to support the ruling party in one district in that election could cost as much as $\$ 4$ million, not including payments to brokers (Wang and Kurzman, 2007). A survey of Nigerian voters found a similar result, with a plurality of respondents saying they would accept a payment but vote for the candidate of their choice (Bratton, 2008). This problem does not diminish with scale: a study of Costa Rica's elections in the first half of the twentieth century found that a major vote-buying effort in a presidential election could cost as much as twenty percent of a candidate's budget (Lehoucq and Molina, 2002, pp. 159; 169; Lehoucq, 2007). The 'leakiness' of extra-legal mobilization represents a real loss of resources, and risks not generating enough votes to win the election.

Compared to the networks of brokers and voters associated with extra-legal mobilization, election fraud and ballot stuffing require the cooperation of a relatively small number of easily-monitored officials. In Russia, the case studied here, election commissions at the national, regional, sub-regional, and precinct levels are responsible for counting, tabulating and releasing election results. The number of voting members of these commissions ranges from three in the smallest precincts to sixteen in the largest (Central Election Commission, 2009). An observation report of the 2011 legislative election in Russia noted 'an informal link between election officials and the state apparatus, which was affiliated with the governing party in the majority of regions observed' (OSCE, 2012). Golosov (2011) writes that the regional administrations 'have gained complete control over the system of regional electoral commissions,' and describes this relationship as a 'well-functioning hierarchy' that links the incomes and career prospects of rank-andfile electoral workers, regional bureaucrats, and regional governors to the electoral success of the ruling party (p. 637). Regional

\footnotetext{
1 This risk also increases the cost of falsification and ballot stuffing. In Russia, for example, half of regional commission members are appointed by the regional legislature ('On the Guarantees ... ' Article 23). A larger delegation in the legislature for opposition parties can thus translate into a less supportive commission.

${ }^{2}$ It can have a variety of goals, as well. Gans-Morse et al. (2014) identify four types of electoral clientelism, based on who is targeted: vote-buying, turnoutbuying, abstention-buying, and double-persuasion.
} 
governors allegedly receive targets for turnout and support for United Russia, which they in turn demand that their subordinates in the electoral bureaucracy produce (White, 2011). Similar linkages between the ruling party and the electoral administration have been noted by observers in other post-communist countries (Bader, 2012; OSCE, 2011; OSCE, 2010; OSCE, 2013).

Election commissioners working on behalf of a party or candidate can falsify election protocols, inflating or deflating vote-totals as necessary. They can also stuff ballot boxes themselves, or turn a blind eye when others do so. In authoritarian countries, coercing or co-opting precinct officials is relatively straightforward: electoral commissions can be dominated by the ruling party, and judicial punishment for electoral malfeasance is likely to be rare (Magaloni, 2010; Popova, 2006). Under such conditions, large numbers of progovernment votes can be manufactured (or opposition votes discarded) at relatively low cost. Neither election fraud nor ballot stuffing necessarily involves direct contact with voters.

Election fraud and ballot stuffing rely on small networks of election officials, while extra-legal mobilization requires large networks that reach all the way to individual voters (and are prone to principal-agent problems). The two former strategies are more cost-effective and reliable ways to generate votes, so long as commission members can be controlled (which appears to generally be the case in Russia). If patrons and brokers choose to engage in extra-legal mobilization, then, it must have additional benefits beyond the ability to deliver clients to the voting booth.

\subsection{Extra-legal mobilization as investment in (de)mobilizing networks}

Extra-legal mobilization efforts require investments in networks that link patrons, clients and brokers in support of the ruling party. Authoritarian governments can use these networks to motivate voters during elections and increase the likelihood of a regime victory. However, such networks also provide authoritarian governments with a tool for mobilizing supporters and demobilizing opponents in the event of street protests. This benefit of extra-legal mobilization-as an insurance policy against opposition action in the street-is most valuable in places where the opposition has the capacity to organize such action.

Clientelist networks have traditionally been thought of as a demobilizing influence, whereby patrons wield their influence to make clients' collective action less likely (Rock, 1972; O'Donnell, 1992; Holzner, 2007). This demobilizing effect can be useful during elections by encouraging opposing voters to abstain (GansMorse et al., 2014; Cox and Kousser, 1981; Schaffer, 2002), but can also have a broader effect by limiting opportunities for antiregime action on the part of clients (Fox, 1994; Grzymala-Busse, 2008; Wintrobe, 2000). The ability to demobilize clients is only one possibility, however. Recently, researchers have recognized the role such networks can have in mobilizing clients to demonstrate active support for patrons outside the voting booth.

Auyero et al. (2009) provide evidence of patrons using their networks to mobilize clients in political activity (both violent and nonviolent), in pursuit of goals beyond electoral success. In their cases, clients were mobilized to blockade major highways, loot small businesses, and even burn down part of a poor neighborhood to send a message about territorial control. Patronage networks have also been found to be important in mobilizing contentious action in Indonesia (Kalyvas, 2003), Colombia (Schmidt, 1974), and Japan (Broadbent, 1999). As Auyero et al. (2009, p. 12) write, 'Wellfunctioning patronage networks can be purposively activated to conduct politics by other collective (and sometimes violent) means'.

Patronage networks have also been used to promote nonelectoral collective action in Russia. Russia's regional governors have considerable access to patronage resources (Hale, 2007; Stoner-Weiss, 1999), and often mobilized their clients in protests aimed at Moscow during the 1990s (Robertson, 2011). Unifying the elite and bringing regional patronage networks under the Kremlin's control was consequently a priority of the Putin administration from its earliest days (see Reuter, 2010; Robertson, 2011, Colton and McFaul, 2003). In response to anti-government protests in 2005, Russian authorities relied on these networks to stage progovernment demonstrations in cities across the country. In Moscow, 20,000 turned out in support of Putin and the ruling party. One employee of the city sanitation department in attendance told a journalist that he and his fellow workers had been told to attend and bring five to ten others. 'When the boss asks such things, there is no question of whether to go or not. Everyone has a family to feed,' (Kommersant February 14, 2005). These examples illustrate how the same networks can be used to engage in or deter collective action, and to provide electoral support for incumbents.

It might be objected that some forms of extra-legal mobilization do not require the construction of durable patronage networks. A voter who is rewarded one time for supporting the ruling party, but is not embedded in a long-term clientelistic relationship, would not appear to susceptible to pressure outside of that particular election. Two responses can be offered to this objection. First, though the relationship between brokers and voters may in some cases be ephemeral, the relationship between patrons and brokers is not. Brokers, furthermore, are most effective when they have detailed knowledge of the territory for which they are responsible. Votebuying campaigns require brokers with intimate knowledge of local populations: whose support can be bought, who can be trusted, and what the community's material demands are. A broker in charge of a particular territory must be 'a walking encyclopedia of local knowledge' (Wang and Kurzman, 2007). Using patronage to motivate voters is one way of locating and investing in successful brokers and maintaining their links to the community as a whole (Lust, 2009), even if connections to some individual voters are tenuous. This kind of expertise can be used to mobilize or demobilize clients in a crisis. Second, one-shot transactions do not appear to be the most common expression of extra-legal mobilization. Even when voters are provided with discrete benefits like cash or food for votes, such exchanges are more often couched in "webs of exchange, obligation, and reciprocity sustained over a longer period, in which patrons provide private goods or club goods to their clients' (Kitschelt and Wilkinson, 2007).

\subsection{Patronage networks as signaling devices}

Conducting extra-legal mobilization requires investments in patronage networks. Elections provide an opportunity to display the strength of these networks: using patronage networks to deliver votes shows that the incumbent regime has resources and organizational capacity that can be used to thwart opposition activity (electoral or otherwise). Awareness of this capacity helps induce ambitious politicians to cooperate with the ruling party rather than the opposition (Magaloni, 2006), an effect which reduces the likelihood of divisions within the elite that can lead to mass protest (Hale, 2006; Hess, 2010). Extra-legal mobilization is one way of indicating to career-minded politicians that siding with the ruling party is a winning bet.

A broader informational view of election fraud holds that excessive or blatant manipulation provides information on the strength of the regime to a variety of actors, including voters, candidates, bureaucrats, and more (Simpser, 2013). In this view, these actors are more likely to take actions that support the regime when they perceive it to be strong and durable. Electoral manipulation that is excessive or blatant communicates that the regime is 
'likely to have the resources, capacities and inclinations to overcome or punish opponents, reward supporters, and circumvent the law' (Simpser, 2013, p. 6). If this view is correct, extra-legal mobilization efforts should be a more compelling signal of 'resources, capacities, and inclinations' than election fraud, since the former requires much more significant investments in patronage networks. Activating patronage networks to win votes during an election can have the additional, indirect benefit of convincing actors within and outside the regime to cooperate with incumbents.

\subsection{Extra-legal mobilization and opposition capacity}

Extra-legal mobilization thus has two indirect benefits, beyond improving the ruling party's chance of winning an election: it builds patronage networks, and sends signals about the strength of these networks to other political actors. As a result, I expect extralegal mobilization to become more common and intense in places where the value of these benefits exceeds the considerable resource costs it requires. The value of both benefits increases along with the capacity of the opposition to mobilize its own supporters.

Organized opposition forces are well understood to be a threat to authoritarian government (Rueschemeyer et al., 1992; Collier, 1999; Diamond, 1999). Organized opposition groups can instigate mass protest (Bratton and Van de Walle, 1997, Beissinger, 2002; Thompson and Kuntz, 2004; Tucker, 2007) that can be destabilizing. Where 'political and civic organizations [develop] a capacity to mobilize citizens' to protest and compete in elections, authoritarian governments are at risk of collapse unless they can mobilize their own corresponding resources (Levitsky and Way, 2010).

Consequently, we should expect to see authoritarian governments invest more heavily in pro-regime patronage networks in regions where the opposition is more capable of mobilizing supporters, in order to counteract possible opposition activity. For example, as the capacity of the opposition to stage protests increases, the ability to use a countervailing patronage network to mobilize supporters in response (or demobilize important classes of citizens, e.g. industrial workers) becomes more important. Where an organized opposition presents a genuine career alternative for politicians, a sizeable extra-legal mobilization effort can signal to such actors that the regime's ability to influence elections is backed up by considerable organizational resources. Falsifying election returns or stuffing ballot boxes are less effective at providing these additional benefits, since these tactics do not require the construction of large networks that link incumbent patrons to citizens. However, in regions where opposition groups are lightly organized (or not at all), extra-legal mobilization provides little benefit relative to its cost.

Hypothesis 1. Extra-legal mobilization efforts should be more intense in places where opposition groups are more capable of mobilizing supporters.

\subsection{Electoral falsification, ballot stuffing, and competitiveness}

To fully test the above claims, it is necessary to understand how other forms of electoral manipulation respond to local competitiveness. Falsifying election protocols and stuffing ballot boxes with false ballots both improve the chances that their beneficiary will win the election. However, since they do not involve actual voters, these strategies are not useful for building mobilizational networks in competitive regions. While the relationship between these two strategies is not the main focus of this article, the same logic of competitiveness that influences extra-legal mobilization also affects falsification and ballot stuffing. As discussed below, falsification is expected where competition is lowest, while ballot stuffing should occur at middle ranges of competitiveness.

Falsification involves election officials reporting false results on election protocols. Successful falsification requires that officials engage in a criminal activity that could be easily traced back to them personally if exposed, since a sizeable gap between official results and the number of ballots cast can only be explained by malfeasance on the part of the election commissioner. In some cases in the 2011 Russian election, observers were able to record unofficial copies of the election protocol before the final version was released. In one case, published by Golos (2011), the preliminary protocol from a precinct in Dagestan shows only 174 total votes (mostly for United Russia). However, in the official results, United Russia received 1077 votes. Election tampering on this scale is only feasible if officials feel that exposure and punishment is highly unlikely - that is, if the ruling party has consolidated its control over the region.

Hypothesis 2. Election falsification will decrease as political competitiveness increases.

Ballot stuffing is a less risky strategy than outright falsification, since the results are tied to actual ballots (though not actual voters). An election commissioner might look the other way as an agent drops a handful of ballots in the urn (or even do the stuffing himself), but nothing ties the commissioner or the state directly to the manipulation once the deed is done. The strategy is feasible at higher levels of competitiveness as a result. Yet it is still less efficient than falsification, since ballots must be procured and distributed to agents (who must be compensated in some way), and agents can only stuff a few ballots at a time. Finally, since it does not involve large patronage networks, ballot-stuffing does not provide the indirect benefits of extra-legal mobilization. As a result, ballot-stuffing should increase with competitiveness, but not monotonically. Ballot stuffing should become more common as falsification becomes difficult, but-since ballot stuffing lacks indirect benefits that become more valuable at high levels of competitiveness-should not increase continuously as competitiveness rises.

Hypothesis 3. Ballot stuffing should become more common as competitiveness increases until the middle range, and then remain stable.

These three hypotheses are based on the theory that different election manipulation tactics carry different costs and benefits. Falsification is most cost-effective, but requires a high level of unity among political actors. Ballot stuffing requires less political unity, but is less cost-efficient. Finally, extra-legal mobilization is least cost-efficient, but provides additional non-electoral benefits beyond ballot stuffing by building and displaying organizational strength. While I do not directly test the claim that the same people induced by extra-legal mobilization are mobilized for progovernment rallies, it is well-known that such networks are used to mobilize and demobilize citizens. Instead, I test the claim that these networks are most likely to be employed in extra-legal mobilization at election time in competitive regions.

\section{Research design}

To test these hypotheses, I draw on the results of the 2011 parliamentary election in Russia. The dataset consists of over 94,000 precinct-level returns, nested within 83 regions. I adapt existing electoral forensic methods to estimate measures of extra-legal mobilization, falsification, and ballot stuffing from this data. A multilevel model is used to test the relationship between these estimates and three measures of the opposition's organizational capacity. 
Russia's regions in 2011 provide an excellent sample of cases with which to test the theory described above. First, contemporary Russia is an archetypal hybrid regime, where elections are the only legitimate route to political power, but are heavily managed. Second, the political system is hierarchical (Hale, 2010; Reuter, 2010), and regional leaders must deliver votes for the ruling party or run the risk of dismissal (Reuter and Robertson, 2012). In addition, Russia's regions vary considerably in terms of average per capita income, ethnic makeup, and other socio-economic factors. Finally, despite the high degree of political centralization, there is considerable variation in the level of partisan competition across the country, with the ruling party's degree of support in the 2011 election ranging from 40 to 99 percent. The hierarchical nature of Russian federalism, combined with the diversity of its regions, means that a subnational analysis allows holds constant many historical and institutional factors, while still allowing for results that can be generalized.

\subsection{Measuring extra-legal mobilization and ballot stuffing}

Russian electoral law allows citizens to cast an absentee ballot away from their assigned polling place, making multiple voting easier to accomplish. It can also provide brokers with a means of monitoring their clients' voting behavior, if voting takes place outside the polling place. Reports from Golos, the premier nongovernmental election-monitoring organization in Russia, contain numerous examples of such behavior. Golos (2011) reports that 'A large number of reports concerned coercion to obtain absentee ballots,' and described numerous examples of the abuse of the absentee provision. A representative example is reproduced here. ${ }^{3}$

'On December 2, the director [of a construction company] brought together the staff and announced that Saturday would be a day off, but that Sunday [Election Day] would be a working day. All were instructed to obtain absentee ballots on Saturday and to vote at the workplace-strictly for United Russia, under penalty of dismissal (Nizhny Novgorod).'

The absentee ballot enables the leaders of firms and institutions to compel their subordinates to vote en masse and under their supervision. Another tactic is described in a report to Golos:

'In the group were ten people; they paid them ten thousand rubles [approximately $\$ 300$ at the time] so that, on election day, having received absentee ballots, they would ride around in a special car to 37 polling places and vote for United Russia...And this is not the only such voting group!'

As the example illustrates, the absentee ballot helps facilitate socalled 'carousel' voting, where United Russia voters are shuttled from one polling place to another. Since the principal advantage of the absentee ballot as a tool for manipulation is its connection to an actual voter, I use the share of voters voting by absentee in a precinct to construct a measure of extra-legal mobilization.

A large percentage of absentee votes does not itself indicate extra-legal mobilization. Rather, it is the relationship between the percentage of absentee votes and the percentage support for United Russia that is telling. I propose a modification of the measure used by Myagkov et al. (2009), in which a regression coefficient is calculated that relates overall turnout to support for a party. A large, positive coefficient may be suggestive of manipulation using this approach, but since it relies on overall turnout it cannot distinguish

\footnotetext{
3 Translations by the author.
}

between different types of manipulation. Replacing overall turnout with the percentage of absentee votes focuses on extra-legal voter mobilization, while excluding forms of manipulation that do not rely on the absentee ballot. Since the absentee ballot is mainly a tool for vote-buying and voter intimidation, I use a multi-level regression model, described below, to generate estimates of extra-legal mobilization for each of Russia's 83 regions. In a region where extra-legal mobilization is an important aspect of the regime's electoral strength, I expect to see a positive correlation between the percentage of absentee votes and percentage support for United Russia at the precinct level. The larger the coefficient of this regression, the larger the share of absentee votes that went to United Russia, indicating a more intense extra-legal mobilization effort.

The same process is used to estimate the intensity of ballotstuffing efforts, using ballots cast by mobile ballot box in place of absentee voting in the multilevel model. Russian law permits voters who are unable to leave their homes to request that a ballot box be brought to them on election day. Removing the ballot box from the polling place, however, gives officials the opportunity to stuff it with forged ballots. Overall, Golos found that mobile ballot boxes were kept away from observers in 13 percent of monitored precincts. In 23 percent of monitored precincts, election officials did not announce the number of applicants for mobile voting before the mobile boxes were opened and the results tallied (Golos, 2011). Two examples from Golos describe the process.

The chair of the [electoral] commission did not announce the beginning of the mobile voting, or show the register [of mobile voters]. Afterward, 296 people were on the list, which is too many for voting at home. All 296 people were visited in 1.5 hours.

They refused to show the mobile ballot box to observers following mobile voting. They took the urn to another floor and closed it in an office.

International observers reported similar problems in a majority of approximately 1500 observed polling places (OSCE, 2012). Mobile votes make up an increasingly large portion of the electorate. In 2011 , mobile votes accounted for $6.6 \%$ of votes cast, the most of any Duma election, while absentee voting accounted for just shy of two percent of total votes (Golos, 2011).

I do not claim that all votes cast by absentee or the mobile ballot box are fraudulent; certainly legitimate voters may make use of these tools. Nor do I argue that these measures capture all efforts to mobilize voters or stuff ballot boxes. These measures do not cover instances where individuals are pressured to cast a standard vote at their own polling place, or when an agent drops a handful of ballots into the stationary ballot box. However, I do argue that a positive correlation between absentee or mobile voting and the rulingparty's vote share can be taken as an indicator of these types of manipulation-approaches which have been frequently noted by election observers.

Finally, these measures are not perfect. In some cases the mobile ballot box will be used to pressure voters, by appearing to give officials or employers the ability to violate the secret ballot. In some cases, absentee ballots may be used to stuff ballot boxes. However, any blending of this sort should make it more difficult to distinguish any empirical differences between the two measures. That is, the imperfection of the measures makes the empirical test used here more difficult, rather than easier.

\subsection{Digits tests and falsification of results}

Finally, it is necessary to measure falsification by election 
officials. Human beings are poor random-number generators, and tampering with election returns by officials leaves detectable traces as a result. In an election where no post-hoc rigging takes place, the distribution of trailing digits in the totals for each party should be uniform across all precincts. That is, the one's digit for a particular party's vote total in a given district is a random product of that precinct's voters' idiosyncratic decisions to vote. Each digit from 0 to 9 should occur in approximately 10 percent of precincts (Beber and Scacco, 2012).

The probability that an underlying uniform population distribution would produce a non-uniform sample distribution due to chance can be ascertained using a chi-square test. To score falsification in this study, I conducted chi-square tests of uniformity for trailing digits of the vote totals of the four parties that won seats in the Duma in 2011, in each of Russia's 83 regions. This information was used to create a variable, Fraud score, which ranges from 0 to 4 . $^{4}$ Each region received a point on this scale for each party that returned a p-value of less than .05 in the chi-square test.

\subsection{Control variables}

The misuse of absentee voting and the mobile ballot box in the 2011 election has been documented by observers, which provides an important justification for using the measures given above. In the more general sense, however, absentee and mobile votes are simply special forms of turnout. These votes are not drawn from the population as a whole, however, but from subsets-people who are ostensibly away from their home polling place (absentee ballots), or unable to reach the polling place (mobile ballot box). As a result, analyzing the relationship between these types of votes and United Russia's share of the vote requires the use of control variables.

Ideally such control variables would be found at the precinct level. Unfortunately such precise data do not exist; consequently all of the control and explanatory variables used in this study are taken at the regional level. These regional-level variables will help explain variation between regions, but not within them. This is appropriate, since regional variation in the relationship between absentee/mobile voting and support for the ruling party is the question of interest.

The mobile ballot box is primarily meant to be used by the elderly and by those in hospitals. Consequently, I include the control variable Pensioners in the model. This variable is the number of pensioners in each region, per 1000 residents, as of 2010 (Russian State Statistical Service, 2012. Hereafter, RSSS, 2012). The pensioners variable does double duty, since the elderly are also more likely to find themselves in hospitals on election day.

No data is available on what types of voters might be more inclined to vote by absentee in the Russian context. However, studies of the United States have shown statistically significant effects for age and level of education on propensity to vote by absentee, along with income (Barreto et al., 2006; Dubin and Kalsow, 1996; Karp and Banducci, 2001). Old age is captured by the Pensioners variable described above. Education is measured using the variable Higher Education, which is the number of people in each region who have completed tertiary education, per 1000 population (2010 Russian Census). ${ }^{5}$ Per capita income is the average income of each region in rubles as of 2010 (RSSS, 2012).

I also control for those factors that have been identified as

\footnotetext{
${ }^{4}$ As a robustness check, I also used a dichotomous variable, which equals 1 if any party's electoral data was suspiciously non-uniform. The results of this approach are substantively similar to the results found using Fraud score.

5 Specifically, the Russian degrees of 'bakalavr,' 'spetsialist,' and 'magistr' as of 2010.
}

important in the literature on vote-buying and clientelism. Poverty, low education, and low economic development have all been identified as factors that can make an individual more susceptible to vote-buying appeals (Brusco et al., 2004; Kitschelt and Wilkinson, 2007). I therefore include a measure of Poverty, the percentage of citizens with incomes falling below the official poverty line, along with the higher education variable described above (RSSS, 2012).

Monitoring voters' actions is easiest in small, densely-knit communities (Stokes, 2005). In polities with large populations, the political machine must not only deploy more resources to purchase a relevant share of votes, but must also monitor voters across larger, more diffuse networks (Hicken, 2011). To account for this, I include each region's Population in thousands (RSSS, 2012). Additionally, the structure of the economy can influence both the susceptibility of voters and the ease of monitoring by brokers. Large public sectors provide government officials with resources to distribute and the ability to directly oversee a large swath of voters (Kitschelt and Wilkinson, 2007). The same can be said of economic concentration generally. The more centralized an economy is, the more influence particular industries may be able to wield over their employees (Hale, 2007). I include two variables to control for these effects. The variable Government Employment reflects the number of regional and municipal government employees in each region per 10,000 residents (RSSS, 2012). Economic Concentration is constructed using statistical data that reports the percentage share of regional economies attributed to each of fifteen economic sectors: agriculture, mining, manufacturing, retail, and so on (RSSS, 2012). The variable is the sum of the squares of those percentages. ${ }^{6}$

I also include two variables to control for the availability of media in each region. The Newspaper variable refers to the number of copies of newspapers published per 1000 residents (RSSS, 2012) while the variable Internet measures the percentage of surveyed organizations in each region that reported regular use of the Internet (RSSS, 2012).

The last control is a measure of Agricultural Employment, the percentage of the regional population employed in agriculture in 2010 (RSSS, 2012). Agricultural communities are often small, dependent on state-provided goods and services, and economically isolated. As such, Hale (2007) argues that in Russia 'the most electorally powerful gubernatorial machines [can be found] in those regions with the greatest shares of the workforces employed in agriculture.' Insofar as high levels of agricultural employment indicate dependence on the state, it should limit the capacity of opposition supporters to successfully mobilize. Extra-legal mobilization should decline as the proportion of the population engaged in agriculture increases. However, agricultural employment also helps control for a possible confounding factor. Mobile voting is likely to be more common in rural areas; if rural voters are also more inclined to vote for United Russia, then this combination might skew the measure upward in rural regions. Agricultural employment is thus an essential control.

\subsection{Explanatory variables}

The theory described here predicts that extra-legal mobilization is more likely to occur in places where the opposition has a higher capacity to mobilize supporters in collective action, and that other

\footnotetext{
6 This is analogous to the Herfindahl index used in economics and other fields to evaluate the degree of competition among firms in an industry.

7 Though this last variable is somewhat esoteric, and serves as proxy for the general population's connectedness to the internet, it is the best available option. Other estimates of internet access are not available at the regional level.
} 
forms of manipulation respond to competitiveness as well. It is difficult to measure such a concept directly. As a result, I use three different empirical measures of the explanatory variable. Two of these measure electoral mobilization, while the third is a socioeconomic proxy variable. A fourth variable, expert assessments of political openness in the regions, is used in the appendix as a robustness check with supportive results.

While no individual measure perfectly captures the concept, supportive results along all three of the measures used should improve confidence that the theory correctly explains why extralegal mobilization is employed in some places and not others. The first electoral measure is United Russia's margin of victory in the 2011 parliamentary election. This variable, UR Margin of Victory, is simply United Russia's percentage support in each region minus the percentage support of its closest competitor. Since extra-legal mobilization is theorized to be a response to the opposition's ability to mobilize, extra-legal mobilization should be greater in close contests rather than lopsided ones.

The second electoral measure is regional competitiveness, which is defined as the difference between the vote-share of the ruling party and the vote-share of the second-place party in the most recent regional legislative election. In all cases the runner-up was the Communist Party of the Russian Federation (KPRF), the principal opposition party in Russia (Gel'man 2008). The difference between the two parties is then subtracted from one, so that a high score indicates a higher degree of opposition activity. A better showing for the KPRF in the regional election is taken as evidence of a greater ability to mobilize voters, which can indicate opposition unity (Howard and Roessler, 2006), the unpopularity of the regional governor or his/her inability to politically unite regional elites (Reuter, 2013) or the articulation of local issues (Golosov, 2006). I use vote-share rather than seat-share since Russia's regions use a variety of mixed and proportional-representation electoral systems that can vary in how they translate votes to seats (Panov and Ross, 2013). Higher competitiveness scores should be associated with greater extra-legal mobilization activity.

Readers may be concerned that both of these measure, being derived from electoral competition (albeit at different levels), are endogenous to the phenomenon of interest. I hope to address this concern as follows. First, recall that the dependent variable of interest in this model is not United Russia's raw vote-share. In other words, the model does not ask whether extra-legal mobilization improves United Russia's showing in elections. Instead, the dependent variable is the size of the relationship between absentee (or mobile) votes and United Russia's support in each region. It is possible that extra-legal mobilization could be more intensive in regions with high margins of victory for United Russia, but it is also possible that such a strategy might be only employed in places where the party's position is precarious (as predicted here).

Second, I include a non-electoral measure of opposition capacity that can be used to confirm the results of the electoral variables: Percent Russian, the percentage of the regional population made up of ethnic Russians (Russian Census, 2010). This is a plausible proxy for opposition capacity in the Russian context. Since the early days of the Soviet Union, minority ethnicity has been politicized by the central government. From the 1920s, the Soviet government recognized ethnic homelands within the Russian Soviet Republic. Ethnic elites were promoted into leadership positions in the regional party, government, industries, and schools. Minority ethnic identity was reinforced through officially-promoted symbols: national museums, folklore, art, music, and literature (Martin, 2001, pp 9-17).

These titular ethnic regions are among the most devoted to United Russia in the present period (Hale, 2007). As a result of the Putin administration's extensive efforts to subdue the regions and bring them under the authority of the Kremlin (Konitzer and Wegren, 2006), the assets that make political machines in the ethnic territories so powerful-stocks of local political resources, a shared collective identity, and relatively unified elites (Ross 2000; Treisman 1997) - were put in the service of the center. Regions where ethnic Russians predominate allow more political space for opposition activity, while ethnic minority enclaves tend to be politically unified around United Russia. I expect extra-legal mobilization to be rare in Russia's ethnic enclaves for two related reasons: first, the regional political machines in such enclaves are strong enough to deter most competition, and second, the central government has been able to co-opt the machine's pre-existing networks for electoral benefit. In regions where politicized minority ethnicity does not provide a ready-made network, elites are more likely to rely on extra-legal mobilization.

The theory discussed above implies an uncertain relationship between extra-legal mobilization and actual protest by the opposition. The risk of pro-opposition collective action should be elevated in places where the opposition has a greater ability to mobilize supporters (McCarthy and Zald, 1977). However, if the regime is able to construct patronage networks and utilize them to win elections in such places, the theory predicts these networks should act as a deterrent on opposition mobilization by signaling the organizational strength of the regime and de-mobilizing some citizens. In other words, extra-legal mobilization should be employed in places where there is a high risk of opposition activity (which would imply a positive correlation), but should also serve to deter protest (a negative correlation). Consequently, measures of actual protest are not appropriate statistical tests for this theory, and proxies that measure opposition capacity are used instead.

All three variables capture a wide degree of variation. United Russia's margin of victory in 2011 ranges from one percentage point to ninety-nine. Regional competitiveness ranges from .15 at the least competitive extreme, to .93 at the most. Finally, Russian ethnicity ranges from approximately $1 \%$ to $97 \%$ of the population, though most regions are dominated by ethnic Russians.

\subsection{Multilevel model of electoral manipulation}

I test this theory using a multilevel model to estimate the effect of the explanatory variables on extra-legal mobilization and ballotstuffing efforts. The ability to account for hierarchical clusters and to analyze contextual effects across clusters are two of the strengths of multilevel modeling (Steenbergen and Jones, 2002). The estimation occurs in two steps, corresponding to the two levels of the model. At the first level, United Russia's percentage support in each precinct $i$ in region $j$ is modeled as a function of the percentage of absentee (or mobile) votes in that precinct. This produces a regression coefficient $\beta$ for each region $j$ that describes the relationship between absentee (or mobile) voting and support for United Russia there. The larger the coefficient, the more intense the manipulation effort is taken to be. The $83 \beta$ coefficients generated by the first level of the model form the dependent variable at the second level. They are modeled as a function of the control and explanatory variables described above, which produces a vector of regression coefficients $\Phi$. The $\Phi$ coefficients indicate the relationship between the region-level variables and the precinct-level relationship between nonstandard voting and United Russia support, and are therefore the figures of greatest interest here. The model takes the following form.

$y_{i j}=\alpha_{j}+\beta_{j} z_{i j}+e_{i}$

$\beta_{\mathrm{j}}=\Phi_{0}+\Phi \mathrm{X}_{\mathrm{j}}+\mathrm{e}_{\mathrm{j}}^{\beta}$ 
Table 1

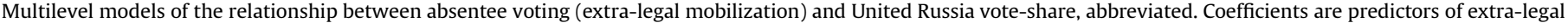
mobilization estimates. Standard errors in parentheses. ${ }^{*}=\mathrm{p}<.1 ;^{* *}=\mathrm{p}<.05$; $^{* * *}=\mathrm{p}<.01$.

\begin{tabular}{|c|c|c|c|c|c|}
\hline & Model 1 & Model 2 & Model 3 & Model 4 & Model 5 \\
\hline UR margin & & $-.98^{* * *}(.26)$ & & & \\
\hline Russian & & & $.70^{* *}(.27)$ & & \\
\hline Competitive & & & & $.73^{* *}(.24)$ & \\
\hline Fraud score & & & & & $-.17^{* * *}(.04)$ \\
\hline Log. pop & $-.23^{* *}(.12)$ & $-.23^{* *}(.11)$ & $-.28^{* *}(.12)$ & $-.24^{* *}(.11)$ & $-.23^{* *}(.11)$ \\
\hline Log. inc. & $.06(.36)$ & $-.30(.32)$ & $.15(.34)$ & $-.04(.34)$ & $.04(.33)$ \\
\hline Poverty & $-.49(1.42)$ & $-2.16(1.3)$ & $-.98(1.35)$ & $-1.34(1.37)$ & $-1.56(1.34)$ \\
\hline Gov. emp. & $-.53^{* *}(.27)$ & $-.41^{*}(.22)$ & $-.49^{* *}(.23)$ & $-.49^{* *}(.22)$ & $-.50^{* *}(.22)$ \\
\hline Pension & $.44^{* *}(.16)$ & $.04(.15)$ & $.10(.18)$ & $.26^{*}(.15)$ & $.20(.15)$ \\
\hline Concentration & $.17(.87)$ & $.08(.77)$ & $.32(.82)$ & $.08(.83)$ & $-.20(.8)$ \\
\hline Internet & $.55(.61)$ & $.19(.53)$ & $.64(.58)$ & $.51(.58)$ & $.48(.55)$ \\
\hline Higher education & $-.08(.17)$ & $-.06(.15)$ & $-.10(.16)$ & $-.11(.16)$ & $-.09(.15)$ \\
\hline Newspapers & $.01(.00)$ & $.00(.00)$ & $.01(.00)$ & $.01(.00)$ & $.01(.00)$ \\
\hline Ag. employment & $-.02(.01)$ & $-.017(.01)$ & $-.015(.01)$ & $-.01(.01)$ & $-.01(.01)$ \\
\hline (Intercept) & $2.83(.49)$ & $.03(.22)$ & $1.21(.47)$ & $1.71(.4)$ & $1.87(.52)$ \\
\hline Percent absentee & $-1.72(1.43)$ & $3.16(1.65)$ & $1.16(.174)$ & $.34(1.74)$ & $.79(1.68)$ \\
\hline Group-level variance & .02 & .002 & .01 & .01 & .02 \\
\hline Individual variance & .03 & .03 & .03 & .03 & .03 \\
\hline Intraclass corr. & .4 & .07 & .25 & .25 & .4 \\
\hline AIC & $-79,820$ & $-80,014$ & $-79,871$ & $-79,900$ & $-79,849$ \\
\hline BIC & $-79,575$ & $-79,750$ & $-79,606$ & $-79,655$ & $-79,585$ \\
\hline Log likelihood & 39,936 & 40,033 & 39,964 & 39,976 & 39,953 \\
\hline Number of obs. & 94,688 & & & & \\
\hline Number of groups & 83 & & & & \\
\hline
\end{tabular}

Table 2

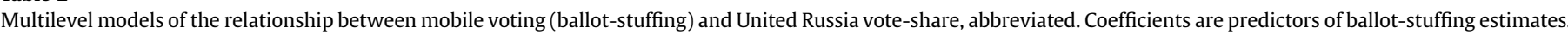
Standard errors in parentheses. ${ }^{*}=\mathrm{p}<.1$; $^{* *}=\mathrm{p}<.05$; $^{* * *}=\mathrm{p}<.01$.

\begin{tabular}{|c|c|c|c|c|c|}
\hline & Model 6 & Model 7 & Model 8 & Model 9 & Model 10 \\
\hline UR margin & & $.76(.48)$ & & & \\
\hline UR margin $^{2}$ & & $-1.59(.57)^{* *}$ & & & \\
\hline Russian ethnicity & & & $1.82(.65)^{* *}$ & & \\
\hline Russian $^{2}$ & & & $-1.26(.54)^{*}$ & & \\
\hline Competitiveness & & & & $2.68(.83)^{* * *}$ & \\
\hline Competitiveness $^{2}$ & & & & $-2.05(.68)^{* *}$ & \\
\hline Fraud score & & & & & $-.13(.03)^{* * *}$ \\
\hline Log. pop. & $.11(.07)$ & $.09(.07)$ & $.09(.07)$ & $.12(.07)$ & $.1(.06)$ \\
\hline Log. inc. & $-.33(.22)$ & $-.6(.21)^{* *}$ & $-.51(.22)^{*}$ & $-.52(.22)^{*}$ & $-.33(.2)$ \\
\hline Poverty & $.81(.9)$ & $-.12(.86)$ & $.24(.87)$ & $.25(.86)$ & $.09(.82)$ \\
\hline Gov. employment & $.09(.11)$ & $.1(.1)$ & $.08(.1)$ & $.11(.1)$ & $.09(.1)$ \\
\hline Pension & $.12(.1)$ & $-.1(.11)$ & $-.05(.13)$ & $.05(.1)$ & $-.07(.1)$ \\
\hline Concentration & $.75(.55)$ & $.83(.51)$ & $.77(.52)$ & $.81(.52)$ & $.44(.5)$ \\
\hline Internet & $-.42(.41)$ & $-.59(.37)$ & $-.5(.39)$ & $-.26(.38)$ & $-.48(.36)$ \\
\hline Higher education & $.04(.12)$ & $.03(.1)$ & $.02(.11)$ & $.05(.1)$ & $.02(.1)$ \\
\hline Newspapers & $.00(.00)$ & $.00(.00)$ & $.00(.00)$ & $.00(.00)$ & $.00(.00)$ \\
\hline Ag. employment & $-.02(.001)$ & $-.02(.01)^{* *}$ & $-.02(.01)^{*}$ & $-.02(.01)^{*}$ & $-.01(.01)$ \\
\hline (Intercept) & $2.2(.64)$ & $-.22(.21)$ & $.88(.49)$ & $1.46(.36)$ & $1.63(.51)$ \\
\hline Percent mobile & $1.33(1.17)$ & $3.7(1.2)^{* * *}$ & $2.41(1.15)^{*}$ & $1.62(1.1)$ & $2.23(1.07)$ \\
\hline Group-level variance & .02 & .002 & .01 & .01 & .02 \\
\hline Individual variance & .02 & .02 & .02 & .02 & .02 \\
\hline Intraclass corr. & .5 & .09 & .33 & .33 & .5 \\
\hline AIC & $-86,924$ & $-87,137$ & $-86,978$ & $-87,021$ & $-86,968$ \\
\hline $\mathrm{BIC}$ & $-86,678$ & $-86,853$ & $-86,694$ & $-86,737$ & $-86,703$ \\
\hline Log likelihood & 43,488 & 43,598 & 43,519 & 43,540 & 43,512 \\
\hline Number of obs. & 94,688 & & & & \\
\hline Number of groups & 83 & & & & \\
\hline
\end{tabular}

\section{Results and interpretation}

Table 1 presents the results of five models that test the relationship between extra-legal mobilization and the variables described above. Table 2 shows the results for ballot-stuffing as the dependent variable. The coefficients in both tables are the $\Phi$ terms, which describe a relationship between the variable listed and the manipulation estimates generated at the first level of the model. The first model in each table provides a baseline where only control variables are included. ${ }^{8}$ The next three models each include one of the three measures of opposition capacity. The last model in each table uses fraud score to test the relationship between falsification and the other two forms of manipulation. In all cases the addition of the explanatory variable improves the log-likelihood, AIC, and BIC

\footnotetext{
${ }^{8}$ A 'full' model that includes all main explanatory variables is not presented here due to multicollinearity concerns. The full model is provided in the appendix.
} 


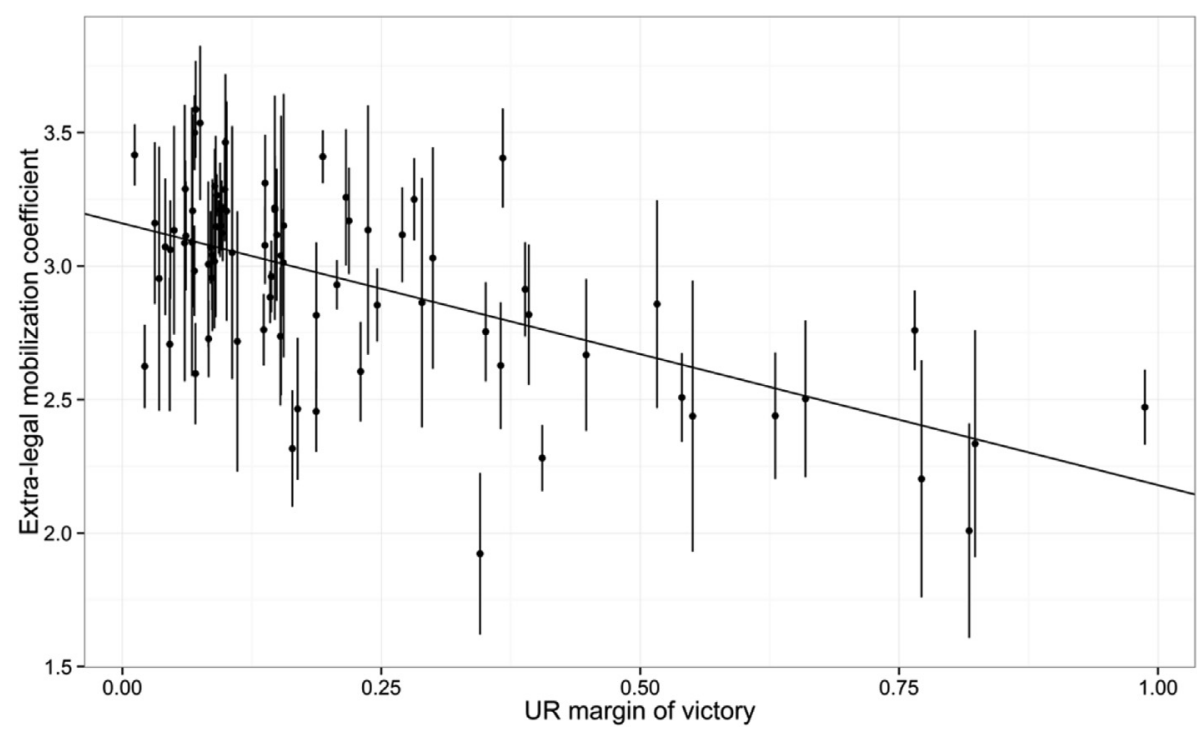

Fig. 1. United Russia's margin of victory and severity of extra-legal mobilization (Model 2).

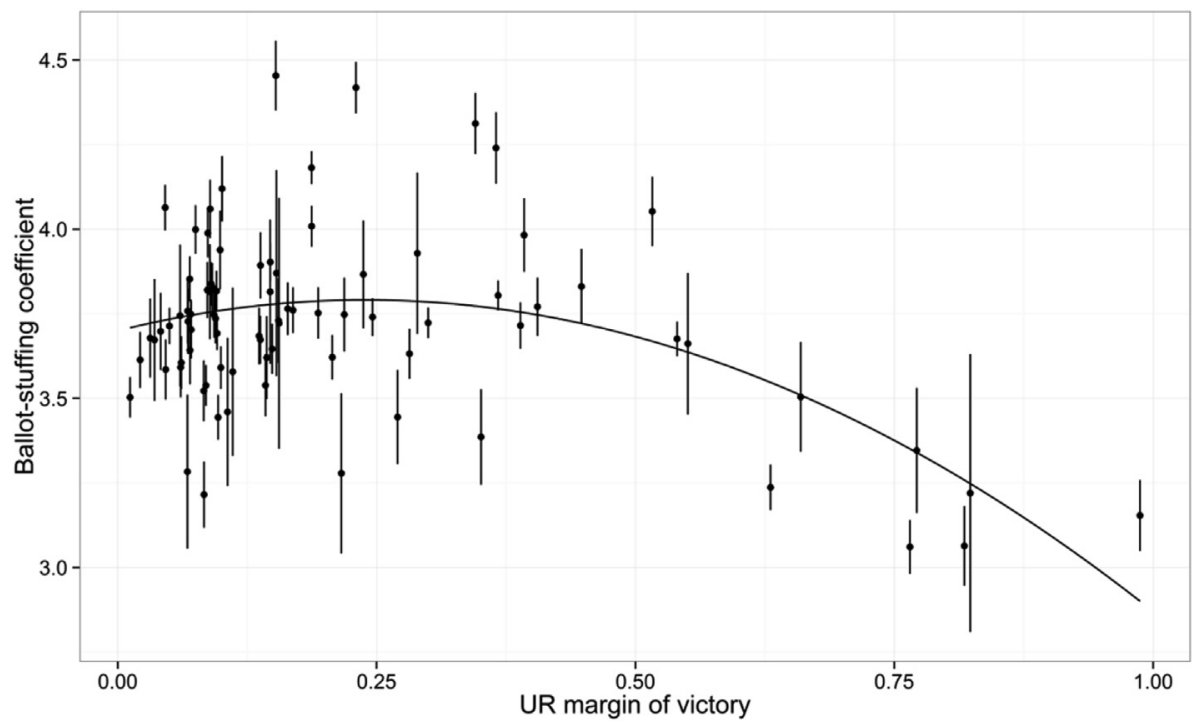

Fig. 2. United Russia's margin of victory and severity of ballot-stuffing (Model 7).

relative to the base model. Taken together, the results of these models make a strong case that ballot stuffing replaces falsification as competitiveness increases, but its use tapers off at high levels of competitiveness. By contrast, extra-legal mobilization efforts increase in a linear fashion as competitiveness rises. ${ }^{9}$

The results are presented graphically in Figs. $1-8$. In each, the points represent a region. The point's value on the y-axis represents the value of the extra-legal mobilization estimate (or ballot-stuffing estimate) for that region. The vertical bars represent $95 \%$ confidence intervals around each estimate. The solid line illustrates the

\footnotetext{
${ }^{9}$ Russian ethnicity and competitiveness are not significant when square terms are used to model extra-legal mobilization. Linear terms for margin of victory and Russian ethnicity are significant when are used to model ballot-stuffing, however the curvilinear models better fit the data according to the AIC and log-likelihood. On the whole, linear models best explain extra-legal mobilization, while curvilinear models best explain ballot-stuffing.
}

coefficient of the relevant variable from Table 1 or $2 .{ }^{10}$ The solid line indicates how the effect of absentee or mobile voting on United Russia's support changes across regions, as the value of the explanatory variable changes.

Fig. 1 shows the relationship between United Russia's margin of victory and extra-legal mobilization. The pattern clearly indicates that this brand of electoral manipulation is employed in regions where United Russia's margin of victory is narrow. In these regions, opposition groups are able to genuinely contest the election, even if the ruling party's ability to rely on patronage networks gives it a distinct advantage. As the influence of opposition parties decreases,

\footnotetext{
10 These figures convey more information than a traditional marginal effect plot, which would use confidence bands to show the range of values for which an interaction term is statistically significant. These figures illustrate the relationship between an explanatory variable and the 83 separate marginal effects estimated for each region, along with the uncertainty inherent in those estimates.
} 


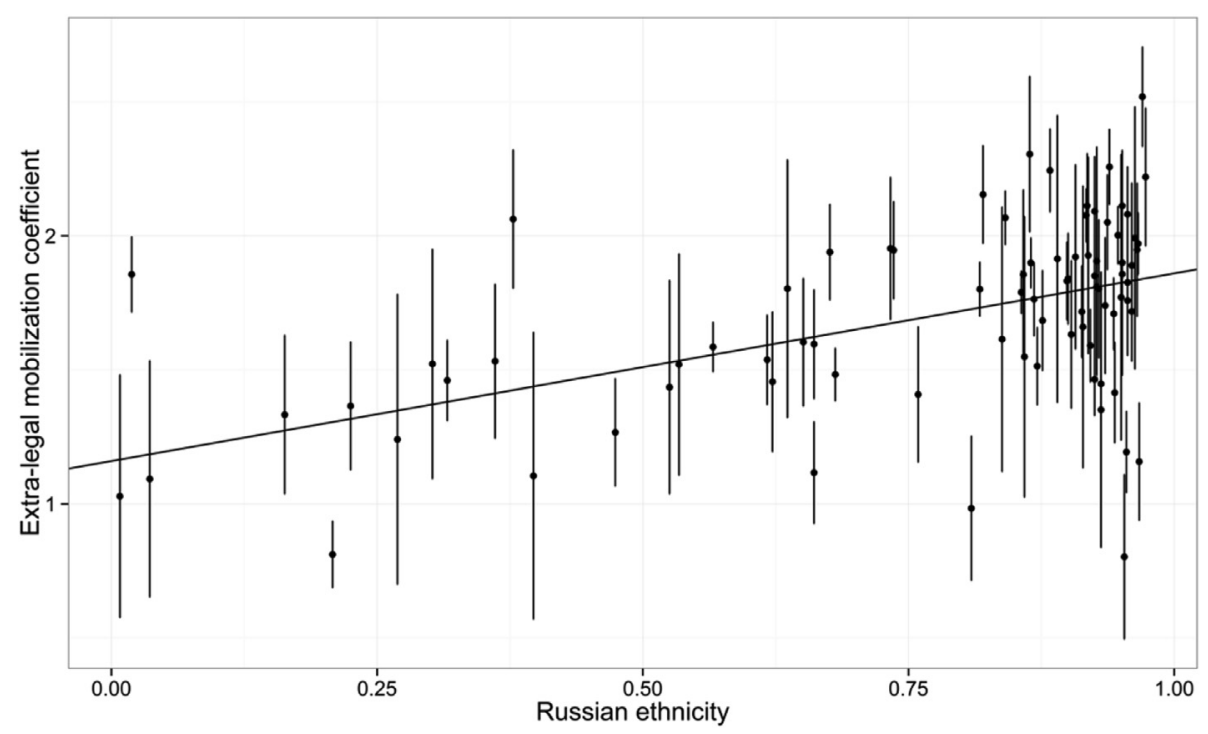

Fig. 3. Russian ethnicity and severity of extra-legal mobilization (Model 3).

extra-legal mobilization estimates decline accordingly. This suggests that in places where the ruling party faces little competition, they do not undertake the expense of mobilizing voters in large extra-legal mobilization efforts via patronage networks. By contrast, as Fig. 2 shows, mobile voting appears hold steady when United Russia's margin of victory is small or moderate, but declines sharply as the margin widens. This suggests that ballot-stuffing is used at similar levels when competition is modest or high, but rarely when competition is low. By contrast, extra-legal mobilization becomes increasingly prominent as competition increases.

A similar effect can be seen when ethnicity is used as a proxy for openness to opposition activity. As shown in Figs. 3 and 4, absentee voting has an increasing effect on United Russia's vote-share as the percentage of ethnic Russians increases, while the effect of mobile voting levels off. Minority enclaves in Russia offer little room for parties to compete with United Russia. As predicted, very little evidence of extra-legal mobilization is detected in regions where ethnic Russians are a minority population. Where ethnic Russians predominate, extra-legal mobilization appears much more intensive. Ballot stuffing, by contrast, is not more common in predominantly Russian regions than in ethnically mixed regions.

The Regional Competitiveness measure shows a similar relationship with extra-legal mobilization estimates (Fig. 5). Where opposition parties generate few votes for the regional legislature, extra-legal mobilization does not appear to be an important part of election management for the ruling party. Extra-legal mobilization becomes more common as the level of competitiveness rises, where opposition parties are able to genuinely contest regional elections. Ballot-stuffing, consistent with the previous models, is most important at the middle range of competitiveness (Fig. 6).

Finally, Figs. 7 and 8 illustrate the relationship between falsification and extra-legal mobilization and ballot-stuffing. In both cases, the relationship is linear and negative. Falsification declines steadily as ballot-stuffing and extra-legal mobilization are employed more intensively.

Taken together, the measures employed here tell the same story. There is strong evidence that falsification occurs predominantly in places where pro-regime political machines are strongest. Regime

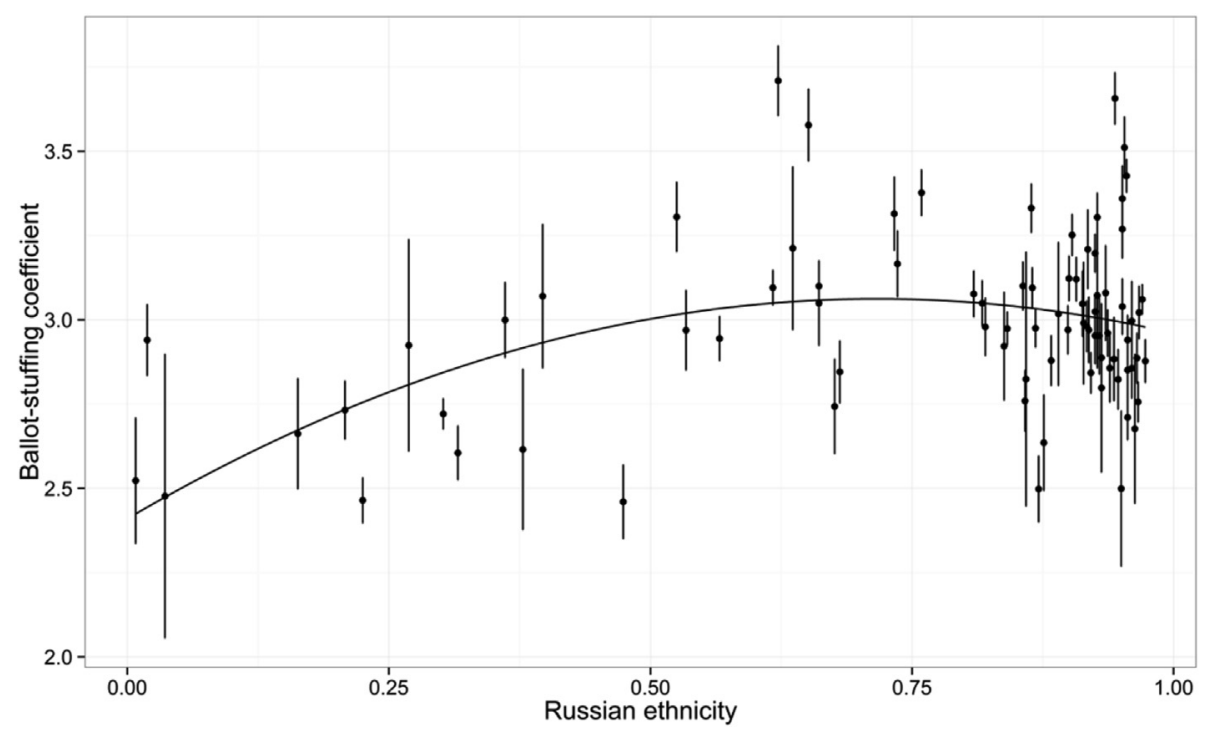

Fig. 4. Russian ethnicity and severity of ballot-stuffing (Model 8). 


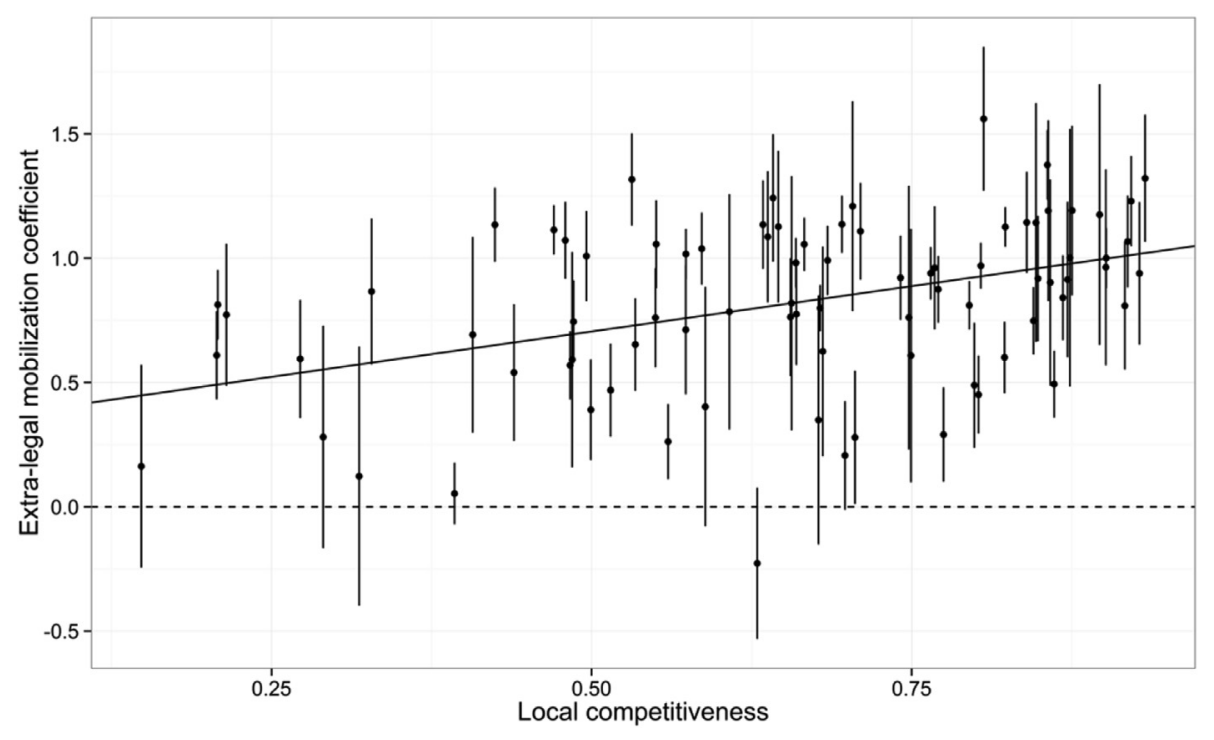

Fig. 5. Local competitiveness and severity of extra-legal mobilization (Model 4).

supporters turn to ballot stuffing when falsification is no longer feasible, due to increased competitive pressure. Ballot stuffing remains part of the manipulation effort, but does not become more intense at the highest levels of competitiveness. Extra-legal mobilization, however, increases steadily as the threat of political competition increases. These patterns can be seen when opposition capacity to mobilize is measured directly using margins of victory in national and regional elections, and when measured indirectly using ethnicity as a proxy.

\section{Conclusion}

This paper began by identifying a puzzle that has gone largely unremarked upon in the literature on election manipulation and hybrid regimes. Extra-legal mobilization efforts are known to be expensive and prone to agency loss and defection. As a result, extra-legal mobilization runs the risk of not generating enough votes to win the election. Why do governments in hybrid regimes undertake these risks, and pay the high costs necessary to implement extra-legal mobilization, when alternatives are available? Why not instead emphasize tampering with the vote count, a process which requires monitoring fewer people and can provide finely targeted election results? Or ballot stuffing, which can be conducted when voters and observers are not present? Manipulation of either sort could also be used to guarantee the slim margins of victory that United Russia claimed in more competitive regions.

To address this puzzle, I have argued that the mix of election manipulation tactics employed varies in response to local political competitiveness. Where competitiveness is very low, supporters of the regime falsify election results. The cost of controlling election commissions, the likelihood of the government's electoral defeat, and the likelihood of anti-regime protest are all low in places where opposition groups lack the ability to mobilize supporters. Rulingparty elites and ambitious politicians already have strong incentives to stick with the ruling party rather than join a weak opposition. With minimal indirect benefits from extra-legal mobilization in such regions, direct falsification is preferred. As

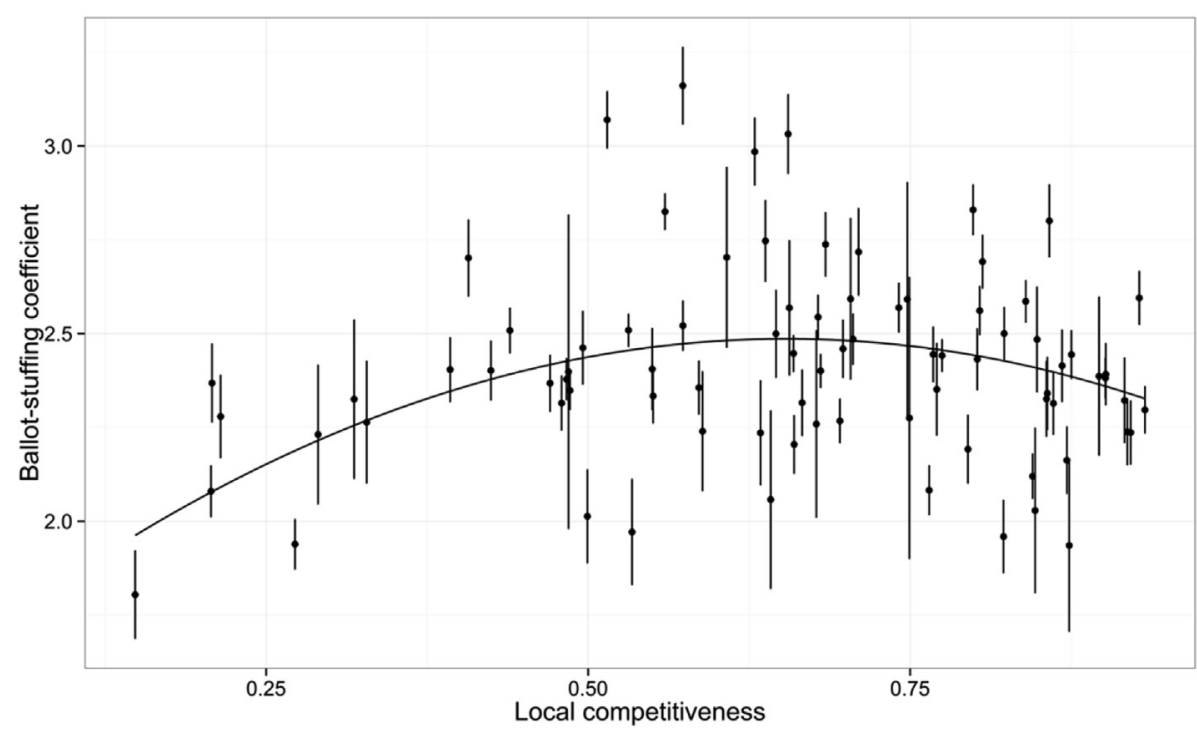

Fig. 6. Local competitiveness and severity of ballot-stuffing (Model 9). 


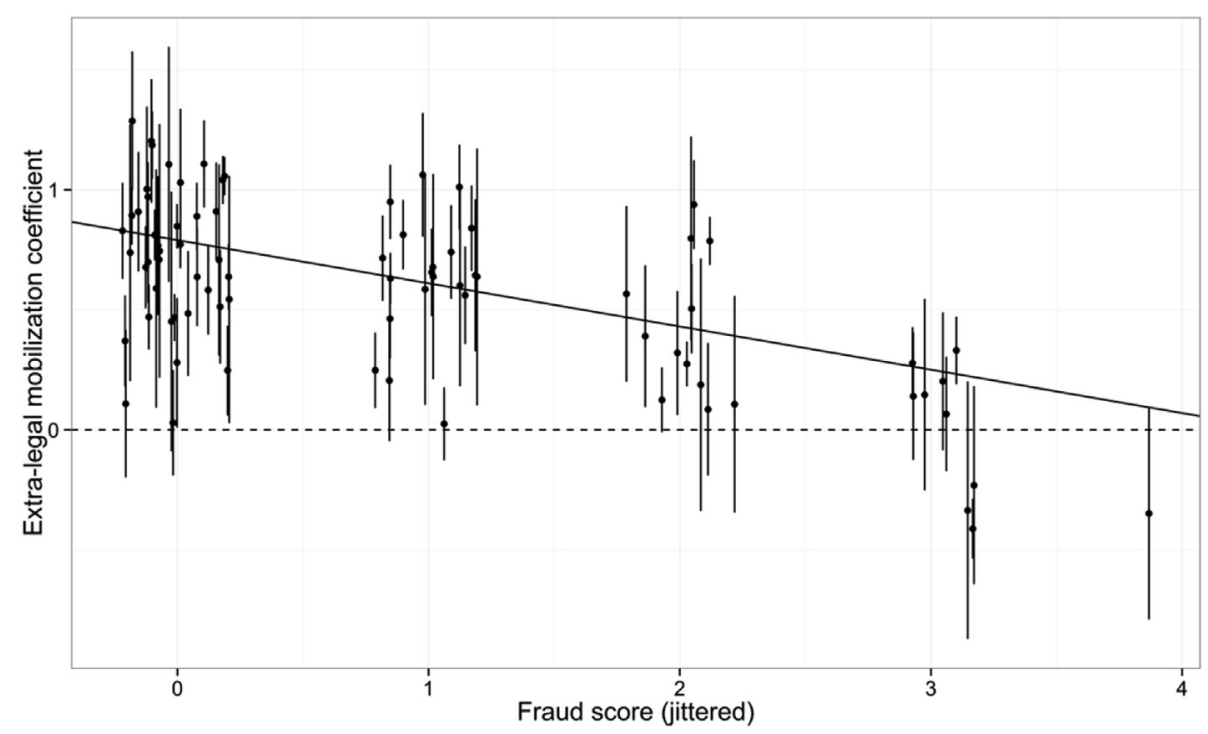

Fig. 7. Fraud score and severity of extra-legal mobilization (Model 5).

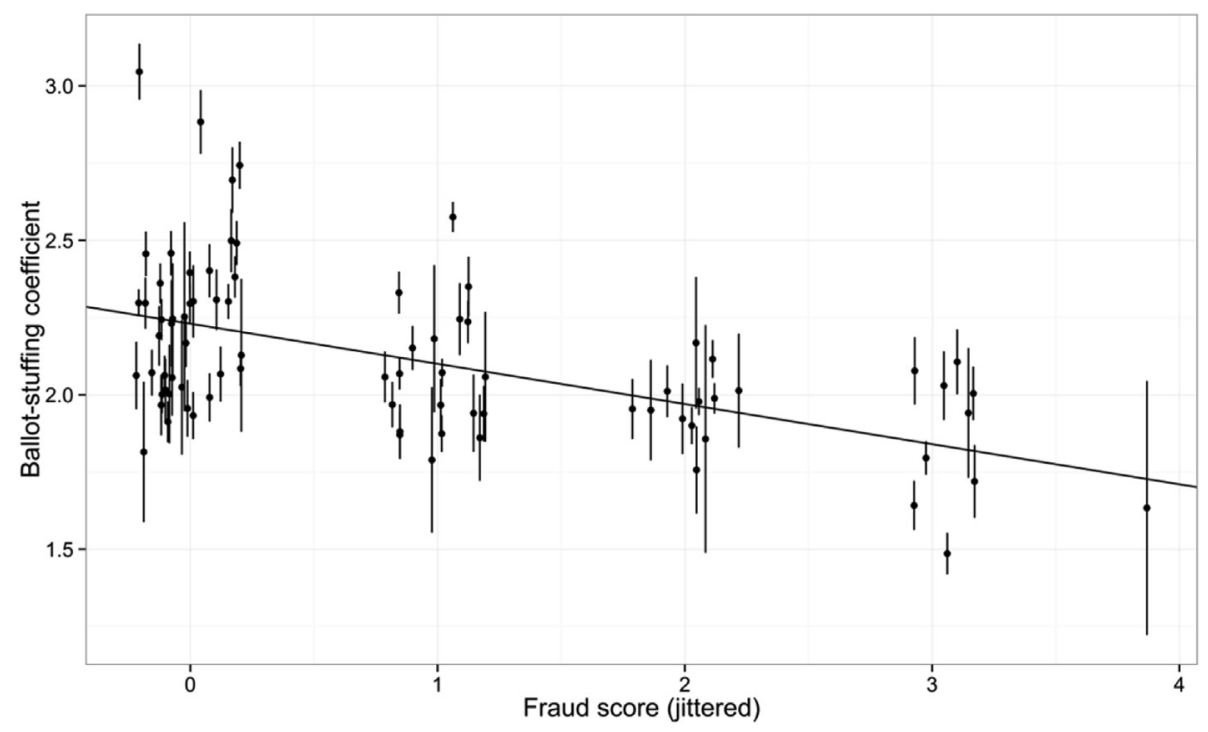

Fig. 8. Fraud score and severity of ballot-stuffing (Model 10).

competition increases, falsification becomes less feasible and ballot stuffing increases in importance. However, ballot stuffing does not increase monotonically with competitiveness. Instead, in places where opposition groups have a high capacity to mobilize, extralegal mobilization becomes an increasingly valuable part of the ruling party's efforts.

Extra-legal mobilization requires investments in networks of patronage that can be used to mobilize voters in the election at hand, but can also be used to mobilize or demobilize clients when necessary. Elections provide an opportunity to build, test and display these networks. Effective use of extra-legal manipulation sends signals about the organizational capacity of the ruling party, which may influence how other political actors behave. The mobilizing and signaling benefits of extra-legal mobilization increase in value as opposition groups become more capable of mobilizing their own supporters. In sum, local political competitiveness structures the mix of tactics with which incumbents seek to manipulate elections in hybrid regimes.

\section{Appendix A. Supplementary data}

Supplementary data related to this article can be found at http:// dx.doi.org/10.1016/j.electstud.2015.11.004.

\section{References}

Auyero, J., 2007. Routine Politics and Violence in Argentina: the Gray Zone of State Power. Cambridge University Press.

Auyero, J., Lapegna, P., Poma, F.P., 2009. Patronage politics and contentious collective action: a recursive relationship. Lat. Am. Polit. Soc. 51, 1-31.

Bader, M., 2012. OSCE electoral assistance and the role of election commissions Secur. Hum. Rights 23, 19-29. http://dx.doi.org/10.1163/187502312800079728.

Barreto, M.A., Streb, M.J. Marks, M., Guerra, F, 2006. Do absentee voters differ from polling place voters? New evidence from California. Public Opin. Q. 70, 224-234.

Beber, B., Scacco, A., 2012. What the numbers say: a digit-based test for election fraud. Polit. Anal. 20, 211-234.

Beissinger, M.R., 2002. Nationalist Mobilization and the Collapse of the Soviet State. Cambridge University Press.

Blaydes, L., 2011. Elections and Distributive Politics in Mubarak's Egypt. Cambridge 
University Press.

Boix, C., Svolik, M.W., 2013. The Foundations of limited authoritarian government: institutions, commitment, and power-sharing in dictatorships. J. Polit. 75, 300-316. http://dx.doi.org/10.1017/S0022381613000029.

Bratton, M., 2008. Vote buying and violence in Nigerian election campaigns. Elect. Stud. 27, 621-632.

Bratton, M., Van de Walle, N., 1997. Democratic Experiments in Africa: Regime Transitions in Comparative Perspective. Cambridge University Press.

Broadbent, J., 1999. Environmental Politics in Japan: Networks of Power and Protest. Cambridge University Press.

Brownlee, J., 2007. Authoritarianism in an Age of Democratization. Cambridge University Press.

Brusco, V., Nazareno, M., Stokes, S.C., 2004. Vote buying in Argentina. Lat. Am. Res. Rev. 39, 66-88.

Bunce, V., Wolchik, S., 2010. Defeating dictators: electoral change and stability in competitive authoritarian regimes. World Polit. 62, 43-86. http://dx.doi.org/ $10.1353 / w p .0 .0043$

Central Election Commission of the Russian Federation, n.d. Electoral Legislation and Process.

Collier, R.B., 1999. Paths Toward Democracy: the Working Class and Elites in Western Europe and South America. Cambridge University Press.

Colton, T.J., McFaul, M., 2003. Popular Choice and Managed Democracy: the Russian Elections of 1999 and 2000. Brookings Institution Press.

Cox, G.W., Kousser, J.M., 1981. Turnout and rural corruption: New York as a test case. Am. J. Political Sci. 646-663.

Diamond, L., 1999. Developing Democracy: Toward Consolidation. JHU Press.

Donno, D., 2013. Elections and democratization in authoritarian regimes. Am. J. Political Sci. 57, 703-716. http://dx.doi.org/10.1111/ajps.12013.

Dubin, J.A., Kalsow, G.A., 1996. Comparing absentee and precinct voters: a view over time. Polit. Behav. 18, 369-392.

Fox, J., 1994. The difficult transition from clientelism to citizenship: lessons from Mexico. World Polit. 46, 151-184.

Frye, T.M., Reuter, O.J., Szakonyi, D.S., 2014. Political machines at work: voter mobilization and electoral subversion in the workplace. World Polit. 66.

Gandhi, J., 2008. Political Institutions Under Dictatorship. Cambridge University Press Cambridge.

Gandhi, J., Przeworski, A., 2007. Authoritarian institutions and the survival of autocrats. Comp. Polit. Stud. 40, 1279-1301. http://dx.doi.org/10.1177| 0010414007305817.

Gandhi, J., Przeworski, A., 2006. Cooperation, cooptation, and rebellion under dictatorships. Econ. Polit. 18, 1-26.

Gans-Morse, J., Mazzuca, S., Nichter, S., 2014. Varieties of clientelism: machine politics during elections. Am. J. Political Sci. 58, 415-432. http://dx.doi.org 10.1111/ajps.12058.

Gel'man, V., 2008. Party politics in Russia: from competition to hierarchy. EuropeAsia Stud. 60, 913-930. http://dx.doi.org/10.1080/09668130802161165.

Golos, 2011. Analytical Report of the GOLOS Association on the December 4, 2011 Elections.

Golosov, G.V., 2011. The regional roots of electoral authoritarianism in Russia. Europe-Asia Stud. 63, 623-639.

Golosov, G.V., 2006. The structure of party alternatives and voter choice in Russia evidence from the 2003-2004 regional legislative elections. Party Polit. 12 $707-725$.

Grzymala-Busse, A., 2008. Beyond clientelism. Comp. Polit. Stud. 41, 638-673. http://dx.doi.org/10.1177/0010414007313118.

Hale, H.E., 2010. Eurasian polities as hybrid regimes: the case of Putin's Russia. J. Eurasian Stud. 1, 33-41.

Hale, H.E., 2007. Correlates of clientelism: political economy, politicized ethnicity, and post-communist transition. Patrons, Clients, Policies Patterns Democr. Account. Political Compet. 227-250.

Hale, H.E., 2006. Democracy or autocracy on the march? The colored revolutions as normal dynamics of patronal presidentialism. Communist Post-Commun. Stud. 39, 305-329.

Hess, S., 2010. Protests, parties, and presidential succession: competing theories of color revolutions in Armenia and Kyrgyzstan. Problems Post-Commun. 57, 28-39. http://dx.doi.org/10.2753/PPC1075-8216570103.

Hicken, A., 2011. Clientelism. Annu. Rev. Political Sci. 14, 289-310.

Holzner, C.A., 2007. The poverty of democracy: neoliberal reforms and political participation of the poor in Mexico. Lat. Am. Polit. Soc. 49, 87-122.

Howard, M.M., Roessler, P.G., 2006. Liberalizing electoral outcomes in competitive authoritarian regimes. Am. J. Political Sci. 50, 365-381.

Kalyvas, S.N., 2003. The ontology of "political violence": action and identity in civil wars. Perspect. Polit. 1, 475-494.

Karp, J.A., Banducci, S.A., 2001. Absentee voting, mobilization, and participation. Am. Polit. Res. 29, 183-195.

Kitschelt, H., Wilkinson, S.I., 2007. Patrons, clients and policies: patterns of democratic accountability and political competition. Cambridge University Press.

Knoke, D., 1990. Networks of political action: toward theory construction. Soc Forces 68, 1041-1063.

Kommersant, Милова, Е., Савина, Е., February 14, 2005. ВладиМиру Путину ПоЖелали Вечного Царства (An eternal kingdom wished for Vladimir Putin).

Konitzer, A., Wegren, S.K., 2006. Federalism and political recentralization in the Russian Federation: United Russia as the party of power. Publius J. Fed. 36, 503-522.

Lazar, S., 2007. El Alto, Rebel City: Self and Citizenship in Andean Bolivia. Duke University Press.
Lehoucq, F., 2007. In: Schaffer, F.C. (Ed.), When Does a Market for Votes Emerge? Elections for Sale: the Causes and Consequences of Vote Buying. Lynne Rienner Publishers, Boulder, CO, pp. 33-45.

Lehoucq, F.E., Molina, I., 2002. Stuffing the Ballot Box: Fraud, Electoral Reform, and Democratization in Costa Rica. Cambridge University Press.

Levitsky, S., Way, L., 2010. Competitive Authoritarianism: Hybrid Regimes After the Cold War. Cambridge University Press.

Lindberg, S.I., 2009. Democratization by Elections: a New Mode of Transition. Johns Hopkins University Press.

Lust, E., 2009. Competitive clientelism in the middle East. J. Democr. 20, 122-135.

Lust-Okar, E., 2006. Elections under authoritarianism: preliminary lessons from Jordan. Democratization 13, 456-471.

Magaloni, B., 2010. The game of electoral fraud and the ousting of authoritarian rule. Am. J. Political Sci. 54, 751-765.

Magaloni, B., 2006. Voting for Autocracy: Hegemonic Party Survival and Its Demise in Mexico. Cambridge University Press New York.

Malesky, E., Schuler, P., 2010. Nodding or needling: analyzing delegate responsiveness in an authoritarian parliament. Am. Political Sci. Rev. 104, 482-502. http://dx.doi.org/10.1017/S0003055410000250.

Martin, T.D., 2001. The Affirmative Action Empire: Nations and Nationalism in the Soviet Union, 1923-1939. Cornell University Press.

McCarthy, J.D., Zald, M.N., 1977. Resource mobilization and social movements: a partial theory. Am. J. Sociol. 1212-1241.

Myagkov, M., Ordeshook, P.C., Shakin, D., 2009. The forensics of election fraud: Russia and Ukraine. Cambridge University Press.

Nichter, S., 2008. Vote buying or turnout buying? Machine politi and the secret ballot. Am. Political Sci. Rev. 102, 19-31. http://dx.doi.org/10.1017/S0003055408080106.

O'Donnell, G., 1992. Transitions, continuities, and paradoxes. Issues Democr. Consol. New S. Am. Democr. Comp. Persp. 17, 56.

OSCE, 2010. Tajikistan, Parliamentary Elections, 28 February 2010: (Final Report).

OSCE, 2011. Azerbaijan, Parliamentary Elections, 7 November 2010: (Final Report).

OSCE, 2012. Russian Federation: Elections to the State Duma, 4 December 2011.

OSCE, 2013. Ukraine, Parliamentary Elections, 28 October 2012: (Final Report).

Panov, P. Ross, C. 2013. Patterns of electoral contestation in Russian regional assemblies: between "competitive" and "hegemonic" authoritarianism. Demokratizatsiya J. Post-Soviet Democr. 21, 369-399.

Popova, M., 2006. Watchdogs or attack dogs? The role of the Russian courts and the central election commission in the resolution of electoral disputes. Europe-Asia Stud. 58, 391-414. http://dx.doi.org/10.1080/09668130600601800.

Reuter, O.J., 2013. Regional patrons and hegemonic party electoral performance in Russia. Post-Soviet Aff. 29, 101-135.

Reuter, O.J., 2010. The politics of dominant party formation: United Russia and Russia's governors. Europe-Asia Stud. 62, 293-327. http://dx.doi.org/10.1080/ 09668130903506847.

Reuter, O.J., Robertson, G., 2012. Sub-national appointments in authoritarian regimes. J. Polit. 74 (4).

Robertson, G.B., 2011. The Politics of Protest in Hybrid Regimes: Managing Dissent in Post-Communist Russia. Cambridge University Press.

Rock, D., 1972. Machine politics in Buenos Aires and the Argentine radical party, 1912-1930. J. Lat. Am. Stud. 4, 233-256.

Ross, C., 2000. Federalism and democratization in Russia. Communist PostCommunist Stud. 33, 403-420.

Rueschemeyer, D., Stephens, E.H., Stephens, J.D., 1992. Capitalist Development and Democracy. University of Chicago Press.

Russian Census, 2010. All-Russia Population Census 2010.

Russian State Statistical Service, 2012. Regions of Russia: Socioeconomic Indicators.

Schaffer, F.C., 2002. Might cleaning up elections keep people away from the polls? Historical and comparative perspectives. Int. Political Sci. Rev. 23, 69-84.

Schedler, A., 2002. The menu of manipulation. J. Democr. 13, 36-50. http:// dx.doi.org/10.1353/jod.2002.0031.

Schmidt, S.W., 1974. La Violencia revisited: the clientelist bases of political violence in Colombia. J. Lat. Am. Stud. 6, 97-111.

Simpser, A., 2013. Why Governments and Parties Manipulate Elections: Theory, Practice, and Implications. Cambridge University Press.

Sjoberg, F.M., 2013. Autocratic adaptation: the strategic use of transparency and the persistence of election fraud. Elect. Stud. 1-13. http://dx.doi.org/10.1016/ j.electstud.2013.08.004.

Steenbergen, M.R., Jones, B.S., 2002. Modeling multilevel data structures. Am. J. Political Sci. 218-237.

Stokes, S.C., 2005. Perverse accountability: a formal model of machine politics with evidence from Argentina. Am. Political Sci. Rev. 99, 315-325.

Stoner-Weiss, K., 1999. Central weakness and provincial autonomy: observations on the devolution process in Russia. Post-Soviet Aff. 15, 87-106.

Thompson, M.R., Kuntz, P., 2004. Stolen elections: the case of the Serbian October. J. Democr. 15, 159-172.

Treisman, D.S., 1997. Russia's "ethnic revival": the separatist activism of regional leaders in a postcommunist order. World Polit. 49, 212-249.

Tucker, J.A., 2007. Enough! Electoral fraud, collective action problems. PostCommunist Colored Revolut. 5, 535-551. http://dx.doi.org/10.1017/ S1537592707071538.

Wang, C.-S., Kurzman, C., 2007. Dilemmas of electoral clientelism: Taiwan, 1993. Int. Political Sci. Rev. 28, 225-245.

White, S., 2011. Elections Russian-style. Europe-Asia Stud. 63, 531-556. http:// dx.doi.org/10.1080/09668136.2011.566423.

Wintrobe, R., 2000. The Political Economy of Dictatorship. Cambridge University Press. 